研 究

\title{
悪性疾患における Disseminated intravascular coagulation
}

\author{
川島康 平*
}

はじめに

Thrombosis と hemorrhage とは，悪性疾患 にしばしば認められる合併症である。今世紀初 め Oslar \& McCrar ${ }^{1)}$ が静脈血栓症と癌との関 連に注目したのに始まり，1930年 Jürgen と Trautwein は, coagulation defect にその意義を 見いだそらとし，前立腺癌の広沉転移患者の低 フィブリノーゲン值を報告した2). その後前立 腺癌患者では, 血中のみでなく, malignant prostatic tissue の中にも, Fibrinolytic activty が存在することが知られた ${ }^{334)}$ 。それ以来, 悪 性疾患の Thrombohemorrhagic manifestation は 各凝固因子の消費現象として考兄られるよらに なり, 肺癌5), 胃癌6), 腸癌7), 乳癌8) などに, 血栓と出血の合併する所見が報告された。 今日 まで,こうした現象に Consumption Coagulopathy ${ }^{9)}$, Thrombohemorrhagic phenomenon, Defibrination Syndrome, Disseminated intravascular congulation (以下略 DIC) などの種々な名称 が与えられてきた。この現象は，基礎疾患の経 過とともに血流中への procoagulant material の 浸入で始まり,フィブリン形成, 血小板凝集が続 き, 時にはこれらが体内臟器などの毛細血管に 血栓として止まる．光学顕微鏡で見られない場 合は，電子顕徽鏡で，Fibrin strands として見 られることがある10).こらした体内でのできご とに対して, Fibrinolytic enzyme system の活性 化が誘起され，血漿水中への Fibrinolytic split products の遊離となる。 かく一連の生体内の動

* 名古屋大学医学部第一内科
きは, 出血傾向の増悪をもたらし, 重篤な状態 をつくりだす。著者らは，DICを早期に診断 し，適切な治療がなされるために， Ethanol gelation test (以下略 EGT) ${ }^{11)}$, Protamine precipitation test (以下略 PPT) ${ }^{12}$ )利用し, 悪性疾 患の DIC に対する抗凝固療法, 血小板輸注に つき症例を中心に述べたい。

\section{I. 材料および方法}

症例は, Wadley Institute (Dallas, Texas, U.S.A)，へ入院した 4 例の悪性疾患で，その 内訳は肺癌, 乳癌, 急性骨髄性白血病, 慢性り ンパ性白血病の各 1 例である.

血液凝固学的検索として, 末梢血小板数, フ ^ブリノーゲン值, Factor V \& VIII assay, Quick prothrombin time, PTTを行ない, intravascular coagulation の検索としては, Breen らの報告による EGT，拈よび Stefan ら の報告による PPT を利用した.

\section{Ethanol gelation test}

1 ) 患者の platelet poor plasma $0.5 \mathrm{~m} l$ と 50 $\%$ ethanol $0.15 \mathrm{ml}$ を混合し, 1 分間静置する.

2 ) その後, 1 分, 5 分, 10分, 15分にゲル 形成: Fibrin Strands 打よび Flakesを観察す る.

判定 : Strong positive $(+3)$ : Clot within 3 $\min$.

positive $(+2)$ : strands within $15 \mathrm{~min}$.

weak positive $(+1 \sim \pm)$ : a very little fibriin at $15 \mathrm{~min}$.

negative $(-)$ : no strands, gel or large fibrin flakes. 


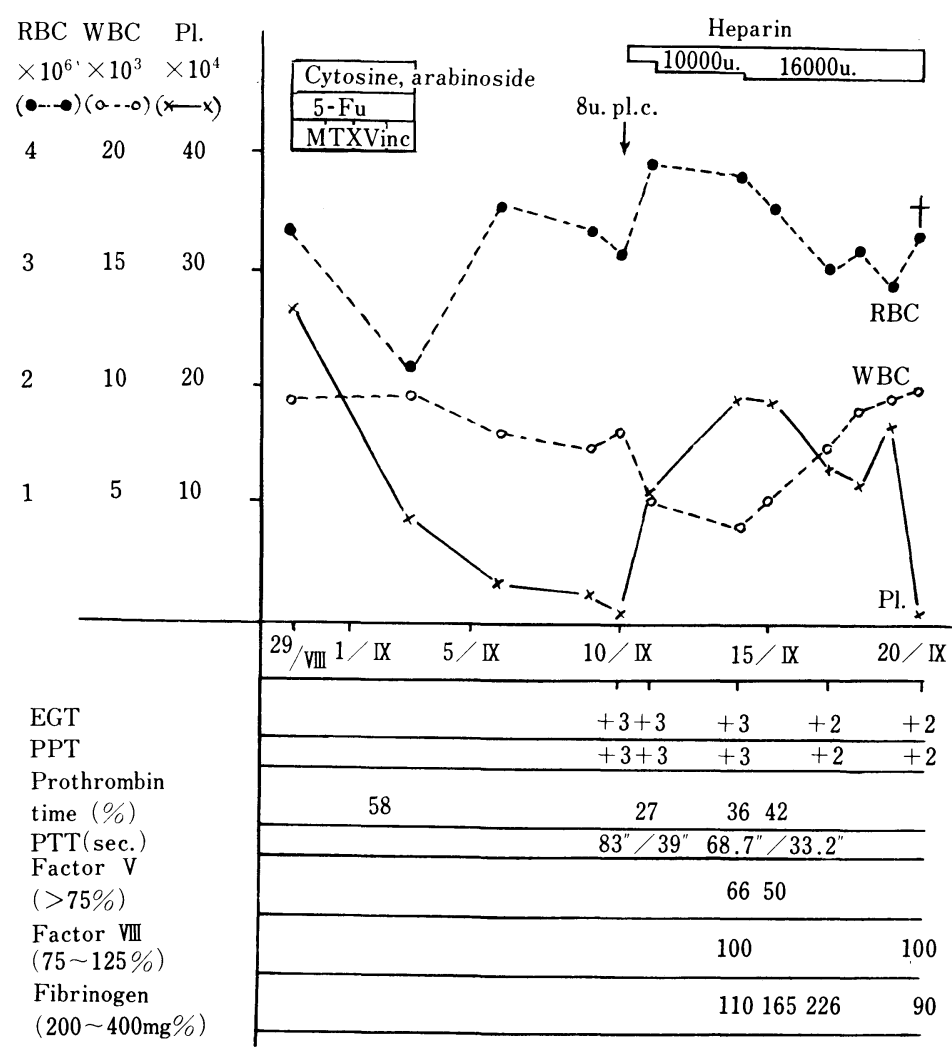

図 1 U.W. 57. F. Breast cancer with metastasis

\section{Protamine precipitation test}

1) protamine sulfate (Upjohn $50 \mathrm{mg}$ vial) を段階稀釈し $1: 5 ， 1: 10,1: 20,1: 40$ をつくる。

2 ) 患者の platelet poor plasma $0.2 \mathrm{ml}$ と protamine sulfate $0.2 \mathrm{ml}$ とを混ぜる.

3） 1 分間静置後, 5 分, 10分, 30分に Fibrin 形成, flakes または fibrin clotsを観察する。

判定 : Strong positive $(+3)$ : fibrin strands or clot within $5 \sim 10 \mathrm{~min}$.

positive $(+2)$ : fibrin strands or flakes in any tube within $30 \mathrm{~min}$.

weak positive $(+1 \sim \pm)$ : positive in $5 \times$ dilution only in 24 hours.

negative: no strand or fibrin or fibrin flakes at $30 \mathrm{~min}$ or 24 hours.

\section{II. 症例}

症例 1 ：(V.W. 転移性乳癌, 図 1 )

1971. 8.29〜9.2 の 5 日間, 転移性乳癌に
対する quadruple chemotherapy ${ }^{13)}$ を投与した ところ，動悸，息切れを訴え，1971．9．2． 肝腫, 脾腫とともに, hemothorax に進展した. 著明な貧血とともに，血小板数も急激に下降 し，全身状態の悪化をきたした。右血胸に Thoracentesis を施行して胸内苦悶の軽減につ とめた. 一方 EGT, PPT ともに強陽性を示し たので, 8 units platelet concentrates とともに ヘパリンを与えた。それとともに血小板数は著 明に増加し，フィブリノーゲン值も上昇し，一 時軽快をみたが，EGT，PPT の陰転化はみられ ず1971. 9.20. 死亡した。

症例 2 ：(H.S. 急性骨髄性白血病, 図 2 )

1971. 8. 6. 全身溢血点を主訴として来 院. 頸部, 腋窩部, 鼠頸部各リンパ節が触れ, 肝 腫，脾腫を認め。 EGT，PPT 陽性を示したが， 血小板数は $10 \times 14^{4} / \mathrm{mm}^{3}$ であり，抗白血病剤 Cytosine arabinoside, Thioguanine, Oncovin $の 3$

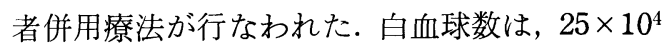
$/ \mathrm{mm}^{3}$ より $1 \times 10^{4} / \mathrm{mm}^{3}$ に減少し, 血小板数も 
図 2 H.S. 15. M Acute myelogenous leukemia

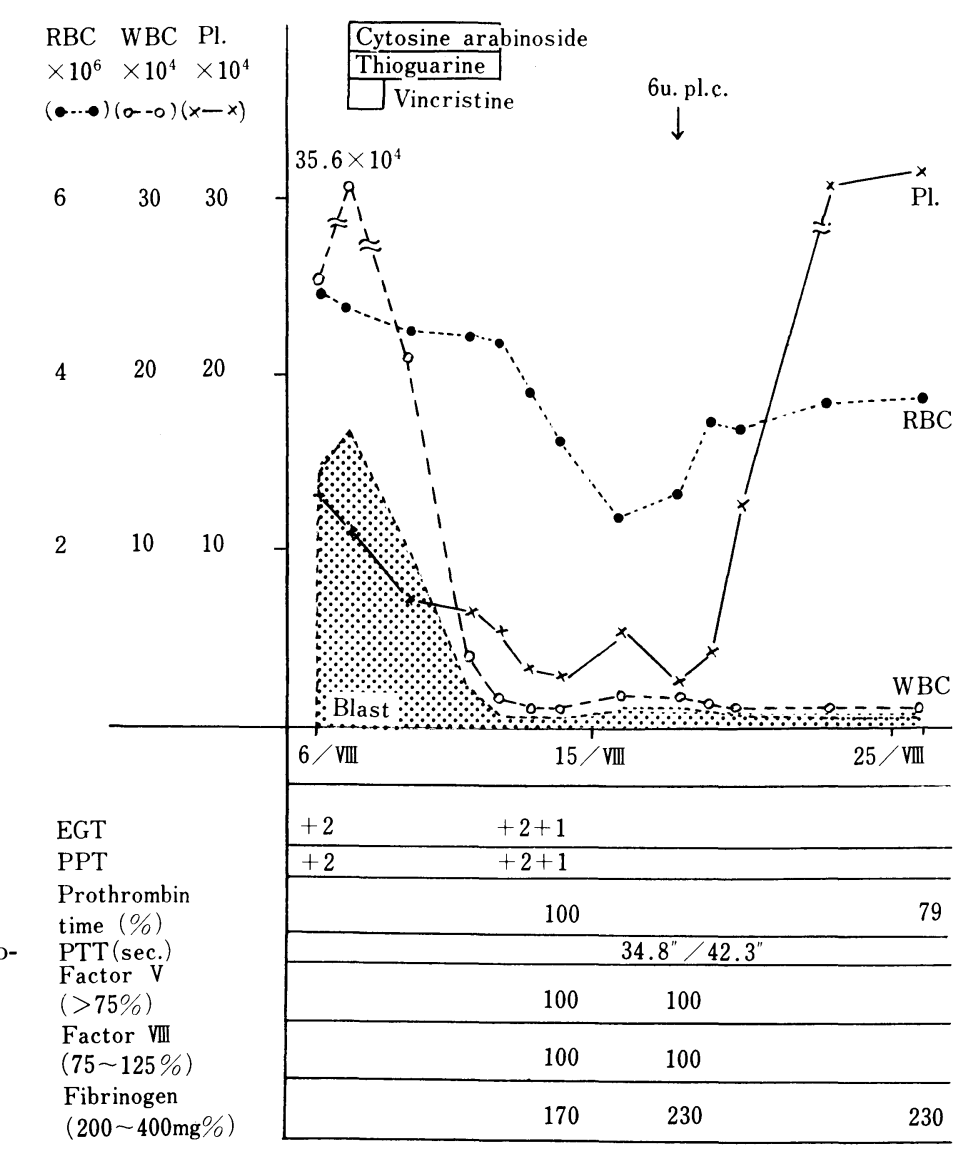

$2 \sim 3 \times 10^{4} / \mathrm{mm}^{3}$ と激減した。 EGT, PPT が 陰転化 した1971. 8．18．に， 6 unit platelet concentrates を与えたところ，血小板数の急激 な上昇をみた，Factor V \& VIII の低下はみら れなかった。

症例 3 : (A.R. 転移性肺癌, 図 3 )

1971. 9. 27. 全身倦急感を主訴として入 院. 肝臓 1 横指, 脾臓 4 横指触知し, 左側に, pleural effusion がみられた。1971９．27より 5 日間の quadruple chemotherapy で, 血小板 数は, 急激に減少し, $43 \times 10^{4} / \mathrm{mm}^{3}$ が $10 \times 10^{4}$ $/ \mathrm{mm}^{3}$ に下降した。それとともに1971．10．5． 約 $300 \mathrm{cc}$ の吐血をみた. packed red blood cell のみにより経過観察したところ, EGT, PPT,陰 転化とともに血小板数の上昇をみた。

症例 4 ：(G.R. 慢性リンパ性白血病, 図 4 )

1971. 10. 2 . 意識消失, 高熱, 出血傾向で 来院し, 血液培養の結果より, E. Coli による,

Bacteremic shock と診断され, 強力な抗生物質 とともに，8 unit platelet concentrates が与兄 られたが，まったく効果はなかった。しかしな がら， EGT，PPT，陰転化した1971. 10. 6亿与 えられた血小板輸注では, 血小板数の上昇が得 られた。

\section{III. 考 案}

Disseminated intravascular coagulation は, 重 大な出血, 血栓形成の症状と関連し, 時には, それが潜在的であるかもしれないが，Carcinomatosis, Leukemia, giant hemangioma, purpura fulminans, hemorrhagic shock, drug reaction $と$ いった多くの臨床疾患で見いだされる．DIC を起こすと考兄られる etiologic factor として は, (a ) intravascular hemolysis, (b ) release of tissue thromboplastin, (c) bacterial endotoxin, (d ) proteolytic enzymes, (e ) particu- 


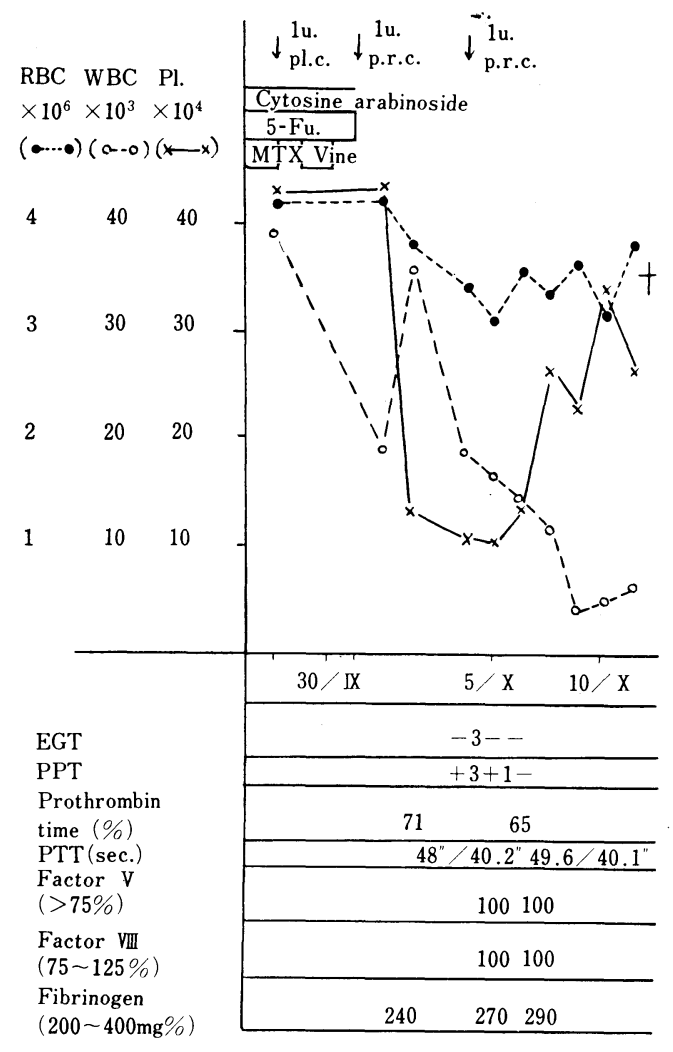

図 3 A.R. 66. M. Pulmonary cancer with metastasis

late or colloidal material, (f ) decreased circulation, ( $g$ ) endotherial damage, $(\mathrm{h})$ ingestion of certain lipid substances などがあげられて いる，悪性疾患に打情 DIC は，しばしば末 期症状として出現すると考学られているため に, 出血を伴う血小板数の減少は, 癌の造血組 織への浸潤によるものと考学られ，そのため に，血小板輸注，凝固剤などをもって，対処さ れるのが一般的で, 抗凝固剂療法が試みられる ことは，一見，その逆説的な治療法のために躊 跲されるのがしばしばである。その理由として は，DIC の確実で手軽な臨床診断法の欠如 とともに体内に批り coagulation system と plasmin system との複雑な関係があるためと思 われる. 現在 DIC の検索法として, Fibrinolytic split productsを測定する Immunodiffusion, Immunoelectrophoresis, tanned red cell hemagglutination inhibition immunoassay が応用され ているが，それぞれ欠点があり，一般臨床応用

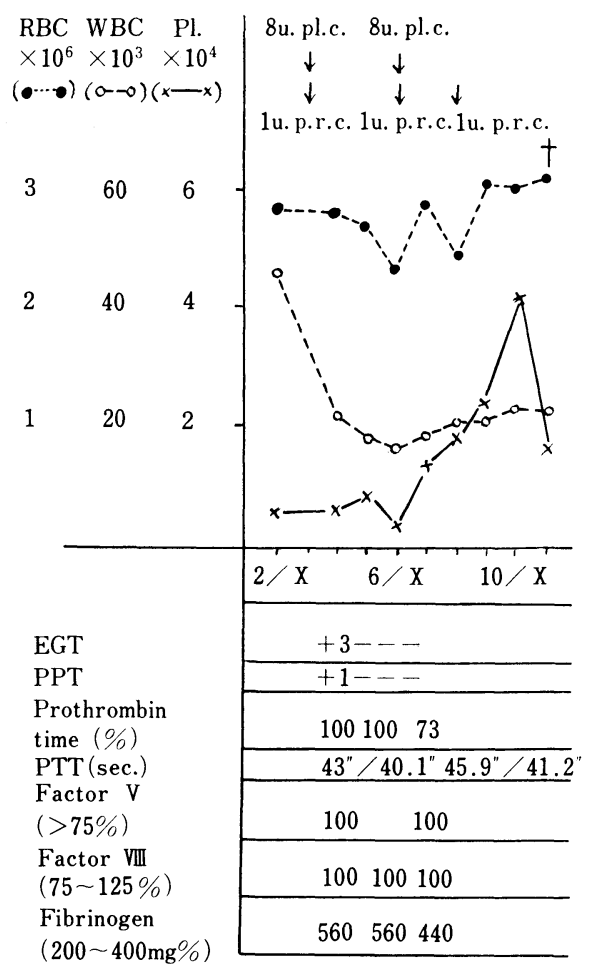

図 4 G.R. 59. F. Chronie lymphatic leukemia

には，十分適さないと思われる。ところが，最 近報告されたPPT は, DIC の semiquantitative assayとして紹介され, fibrin monomer, fibrin degradation product (以下略f.d.p) に特異的に 反応し，その感度は EGT の 20〜40倍といわ れ, 測定しらる最低濃度はf.d.p. $5 \sim 10 \mathrm{mg} \%$, fibrin monomer $2 \sim 5 \mathrm{mg} \%$ と述べられている. DIC の一般臨床検查法としては, 末梢血小板 数, Factor II \& V \& VIII, fibrinogen などの 各凝固因子の低下をもって強調されているが, EGT, PPT の臨床応用は, より適確に, より簡 単に DIC を診断しらるものと思われる。本症 例にみられるごとく, EGT, PPT が陽性を示す にもかかわらず，フィブリノーゲン， Factor V \& VIII の低下が，常には随伴しないことは， 興味があり，凝固因子などの測定による DIC の間接的検査法は, 必ずしも適当とは思われ ない，しかしながら日々の血小板数の変動は DIC 診断の有用な指標でありらることは注目 せねばならない，特に血小板数の急激な減少 
は，DIC による血小板消費を示唆する可能性 がある可能性 がある。凝固因子の 低下を伴う 場合は, 出血症状が激しく, 回復の望み薄い DIC の末期状態であろうと思われる。一方， DIC の治療を考える場合, PPT が陽性の時に, 血小板輸注をすることは，DIC を増悪こそす れ，止血効果は得られそうにない。症例 4 の ごとく, 8 unit platelet concentrates の輸注で は, 約 $10 \times 10^{4} / \mathrm{m}^{2}$ of body surface の増加 ${ }^{14)}$ 期待されるにもかかわらず，輸注前と変らず， PPT 陰転化後では, 血小板数の増加効果が得 られている。また，症例 2 の急性白血病の場 合，抗癌剂による造血組織への抑制効果がみら れなくなる時期で，しかも EGT，PPT の陰転 化時で血小板輸注が行なわれ，著明な効果を得 たことは，血小板輸注の投与時期を選定しうる ものと考学られる. もちろん血小板增加は， histocompatibility, isoantibody, fever などに， 影響されることは忘れてはならない。一方， 一度起こった DIC が抗白血病剤の投与ととも に消腿をみたことは，基礎疾患の改善が，大い に DIC 患者の prognosis に影響することは明 らかである. Anticoagulant therapy が DIC の 治療に有効なことは，すでに報告されているこ とで，本症例にてもへパリン療法と血小板輸注 により，著明な血小板数の改善をみている。こ うしたことは DIC の早期発見の必要性ととも に, 抗凝固剤と血小板輸注の同時療法が有効な DIC 治療法と考兄られる，ただ基礎疾患の状 態によっては，DIC の自然軽快がありらるこ とは，生体内に打ける凝固系，プラスミン系， 網内系の間の複雑な関係を示唆し，治療の困難 性を暗示している，EGT，PPT がいかに，臨床
上有効な DIC 診断法か否かは, 今後の症例で の検討が必要と思われる。

$$
\text { ま と め }
$$

悪性疾患の DICを EGT, PPTをもって診 断し, 各凝固因子との関係, および抗凝固剂療 法, 血小板輸注の投与時期につき症例を中心に 述べた，EGT，PPT は簡便な DIC 診断法とし て臨床上有効であると考兄られる。

\section{文献}

1) Oslar, W., T. McCrae: Philadelphia med. J., 5; $245,1900$.

2) Jurgens, R., H. Trautwein: Dtsch. Arch. Klin. Med., 169; 28, 1930.

3) Tagnon, H.J., et al.: Amer. J. Med., 15; 875, 1953.

4) Tagnon, H.J., et al.: Cancer, 5; 9, 1952. Cohen, S.N., H.G. Kupfer: New Engl. J. Med., 259; 1103, 1958.

5) Biben, R.L., M.L. Tyan: Ann. intern. Med., 49; 917, 1958.

7) Merskey, C., et al.: Blood, 24; 701, 1964.

8) Johnson, A.J., C. Merskey: Thrombos. Diathes. Haemorrh. (Stuttg.) Suppl., 20; 161, 1965.

9) Rodriguez-Erdmann, F.: New Engl. J. Med., 273; 1370, 1965.

10) Mckay, D.J., et al.: Surg. Gynec. \& Obstet., 125; 825, 1967.

11) Breen, F.A., et al.: Ann. Intern. Med., 69; 1197, 1968.

12) Stefan, N., et al.: J. Lab. Clin. Med., 77; 665, 1971.

13) Constanzi, J.J., et al.: Cancer, N.Y., 23; 589, 1969.

14) Freireich, E.J.: Transfusion, 6; 50, 1964. 